\title{
SUAP DAN POLITIK UANG DALAM PANDANGAN FIKIH
}

\author{
Judul Buku \\ : Fikih Korupsi,Analisa Politik Uang di Indonesia \\ dalam Persfektif Maqashid al-Syari'ah \\ Penulis \\ : Dr. Harun al-Rasyid, M.Hum. \\ Penerbit \\ Kencana \\ Cetakan \\ April 2016 \\ Jumlah halaman : $\quad 306$ \\ I S B N \\ : 9786020895819
}

Fikih adalah produk manusia. Ia tidak bersifat absolut. Artinya, fikih dapat dikritik bahkan diperbaharui bila tidak selaras lagi dengan visi kemanusiaan. Wawasan etik sangat diperlukan supaya fikih menjadi selalu aktual dengan konteks Islam rahmatan lil alamin. Demikian Harunal-Rasyid memulai uraiannya dalam buku karyanya yang diberi judul Fikih Korupsi Analisis Politik Uang di Indonesia dalam Persfektif Maqashid al-Syariah.

Buku ini menyoroti praktek politik uang yang marak terjadi menjelang pemilu dan pemilihan kepala daerah (pilkada) di Indonesia. Penulis yang sehari-hari berprofesi sebagai penyidik Komisi Pemberantasan Korupsi (KPK) menyoroti praktek politik uang tersebut dari persfektif fikih yang berlandaskan tujuan syariah (maqashid al-syari'ah).

Politik uang akhir-akhir ini sudah menjadi fenomena yang jamak terjadi. Hampir seluruh proses demokrasi, baik itu pemilihan kepala daerah walikota, bupati, gubernur, anggota legislatif maupun proses yang terkait dengan penempatan jabatan-jabatan strategis di pemerintah, melibatkan politik uang di dalamnya. Bahkan untuk setingkat pemilihan kepala desa sekalipun, politik uang yang terjadi di desda terpencil juga tidak kalah besarnya. Kecerdasan intelektual, kecerdasan emosional, dan kesalehan pribadi tidak menjadi tidak menjadi tolok ukur kelayakan. Dengan kata lalin, bahwa politik uang menjadi penentu dalam kehidupan demokrasi akhir-akhir ini.

Penulis lalu menganalisis penyebab munculnya praktik politik uang. Ia berpendapat bahwa fenomena demokratisasi yang berlangsung sangat cepat di Indonesia ternyata telah menimbulkan masalah baru dalam bidang sosial, poliitik dan hukum di Indonesia yakni maraknya politik uang yang berlangsung hampir di seluruh tingkatan pemilihan umum, sehingga wajar jika John Markoof menyatakan bahwa Indonesia saat ini mengalamoi hybrid demokrasi yakni mekanisme demokrasi yang berlangsung secara bersamasama dengan praktik-praktik nondemokratis (hlm. 7).

Dalam wilayah filsafat, persoalan politik uang ini tampaknya lebih dipandang sebagai persoalan budaya ketimbang persoalan hukum atau lebih tepatnya kemampuan rasional manusia baik sebagai individu maupun sosial. Hal ini mengacu pada konklusi teori filsafat kuno yakni teori naturalisme 
yang dicetuskan oleh Aristoteles yang menyatakan bahwa seseorang bersikap etis atau tidak bergantung pada daya nalarnya, karena ukuran perbuatan baik atau tidak adalah rasio. Demikian juga dalam teori filsafat modern utilitarianisme dari David Hume dan Jeremy Bentham. Bagia keduanya yang menentukan seseorang atau kelompok sosial akan berbuat baik atau sebaliknya adalah kemampuan rasional individu atau kolektif masyarakat dalam menilai apakah sebvuah tindakannya tersebut membawa manfaat atau kerugian.

Berbeda dengan filsafat Barat, konsep pemikiran filsafat hukum Islam menilai bahwa hukum tidak hanya berlaku di dunia saja akan tetapi juga di akhirat, karena putusan kebenaran, atau ketetapan sanksi, di samping berhubungan dengan manusia secara langsung, juga berhubungan dengan Allah SWT. Di samping mengadopsi hukum yang langsung dari wahyu Tuhan yang berbentuk kitab suci, manusia dituntut untuk mencari formula kebenaran yang tersebar dalam kehidupan masyarakat, memberikan makna filosofis dengan mengetahui kebenaran yang hakiki.

Perilaku politik uang dalam konteks politik Indonesia sekarang sering kali diatasnamakan sebagai bantuan, infak, sedekah dan lain-lain. Pergeseran istilah money politics ke dalam istilah moral keagamaan ini secara tidak langsung telah menghasilkan perlindungan secara sosial melalui norma melalui norma kultural masyarakat yang memang melazimkan tindakan itu terjadi. Pada saat masyarakat telah menganggapnya sebagai tindakan lumrah maka kekuatan legal formal hukum akan kesulitan untuk menjangkaunya. Karena itu dibutuhkan kecermatan untuk memahami setiap makna yang tersimpan dibalik perilaku politik sehingga dapat memudahkan dalam pemisahan secara analitis antara pemberian yang sarat dengan nuansa suap dan pemberian dalam arti sesungguhnya sebagai bantuan.

Kesulitan mengambil persepsi yang tegas di kalangan pemimpin masyarakat. Ketika beberapa agamawan menyatakan bahwa politik uang itu haram, penilaian beberapa agamawan yang lain ternyata tidak demikian (tidak menyatakan haram namun juga tidak menyatakan boleh). Sulit dibedakan antara pemberian yang tergolong rishwah (suap) dengan pemberian yang tergolong amal jariyah. Ketidakpastian hukum menjadi salah satu penyebab maraknya praktik politik uang.

Lantas bagaimana upaya mencegah politik uang tersebut? Penulis menawarkan nilai-nilai yang perlu dipraktekkan dalam kehidupan yaitu pertama, memulai kehidupan dan melakukan pekerjaan dengan niat ikhlas. Kedua, menumbuhkan nilai kezuhudan terhadap harta. Ketiga, menumbuhkan perasaan malu dan bersalah bagi pelaku korupsi dan politik uang. Keempat, menumbuhkan nilai kejujuran dan amanah. Kelima, Menghindari sifat Ingin Instan dalam meraih kesuksesan hidup. Keenam, menghilangkan sifat materialistik, kapitalistik, dan hedonistik. Ketujuh, menjaga pikiran untuk bermaksiat. Kedelapan, menjaga ketakwaan kepada Allah SWT. Kesembilan, 
selalu teguh pada ikhtiar. Kesepuluh, menumbuhkan rasa syukur atas nikmat harta dari Allah SWT. Kesebelas, memupuk rasa sabar menghadapi ujian agar tidak terjerumus korupsi dan politik uang. Keduabelas, menumbuhkan perasaan takut kepada Allah.

Membangun konsistensi penegakan hukum terhadap praktik politik uang yang terjadi adalah harus dimulai dari membangun ketaatan kepada hukum. Ketaatan hukum tidak terlepas dari kesadaran hukum. Hukum harus diterapkan secara konsisten, tidak diberlakukan secara diskriminatif, tidak memihak kepada siapa pun dan apa pun, kecuali kepada kebenaran dan keadilan itu senditi. Namun jika hukum diberlakukan diskriminatif, tidak dapat dipercaya lagi sebagai sarana memperjuangkan hak dan keadilan, maka jangan disalahkan jika masyarakat menjadi anomi dan apatis terhadap hukum. Maraknya politik uang utamanya yang terkait dengan politk uang dalam Pemilu Legislatif, pemilihan kepala daerah (pemilukada) salah satu sebabnya adalah tidak pernah ada penanganan yang dapat dikatakan sangat serius terhadap pelanggaran politik uang dimaksud. Penanganannya hanya dilakukan seadanya dan bersifat sporadis saja. Setelah itu politik uang masih berlangsung dan aparat hukumnya seakan merasa frustrasi untuk menanganinya karena kejadiannya terjadi secara merata.

Oleh karenanya hukum harus memiliki kewibawaannya dalam menegakkan supremasi hukum agar masyarakat dapat menghormatinya dalam wujud kepatuhannya terhadap hukum itu sendiri. Dengan demikian, perlunya membangun budaya hukum merupakan suatu hal yang hakiki dalam negara hukum, di mana hukum harus dapat mengubah masyarakat untuk menjadi lebih baik, lebih teratur, lebih bisa dipercaya untuk memperjuangkan hak dan keadilan.

Solusi yang ditawarkan penulis untuk mencegah praktik uang di antaranya adalah membentuk hukum Islam yang progresif. Hukum Islam bersifat tidak kaku. Inilah yang menjadi teori awal untuk mengkaji nilai-nilai hukum dalam kehidupan. Nilai-nilai itulah yang nantinya akan menjawab apakah hukum Islam itu bias menuntaskan permasalahan hukum yang sangat aktual. Dalam persfektif filsafat hukum Islam di Indonesia sering ditempatkan pada ruang dogmatis. Yang sarat dengan doktrinitas keagamaan dan kepercayaan tertentu.

Menurut penulis, untuk mencegah praktik politik uang melalui aktualisasi hukum Islam memerlukan upaya yang sungguh-sungguh dari semua elemen masyarakat khususnya yang bergerak di bidang hukum bahwa aplikasi syariah pada tataran wacana ini harus menjadi ladang pembedahan hukum ke depannya. Tujuannya adalah melahirkan hukum yang aktual dan progresif. Semakin banyaknya sarjana-sarjana hukum Islam harus menjadi sarana awal untuk melahirkan hukum Islam yang progresif (hlm. 288).

Wujud progresivitas hukum Islam ini salah satunya dalam bentuk ijtihad yg memungkinkan seorang hakim pidana yang beragama Islam dengan 
menerapkan hukum-hukum yg bermuatan syariah dalam putusan-putusan hukum yg akan dijatuhkannya kepada pelaku politik uang dan korupsi.

Solusi lain yang ditawarkan penulis adalah meningkatkan kesejahteraan pegawai negeri. Faktor gaji kecil yang tidak cukup menjadi untuk memenuhi kebutuhan ditengarai menjadi salah satu sebab pendorong para pedawai negeri dan pemerintah "berkreasi" untuk mendapatkan pendapatan dengan cara yang melawan hukum. Bisa dengan mengambil uang negara atau menerima suap dari pihak-pihak yang berurusan dengannya. Bagaimana mungkin seorang tidak melakukan korupsi, tidak menerima iming-iming janji akan menerima hadiah, bila gajinya relatif kecil, kebutuhannya banyak, sementara dia mengelola uang yang jumlahnya ratusan juta hingga milyaran rupiah. Oleh karena peningkatan pendapatan melalui gaji atau komponen penerimaan yang sah perlu dilakukan.

Islam memerintahkan manusia agar tidak rakus dan tamak terhadap harta. Namun demikian, Islam juga sangat realistis terhadap kehidupan. Di dalam Islam juga terdapat petunjuk idealitas penggajianyang layak. Hadis Nabi agaknya mengakui bahwa walaupun yang paling menentukan lahirnya clean governance adalah mental penguasa atau pejabat, tetapi standar penggajian yang laak menjadi factor yang ikut menentukan.

Prinsip antikorupsi dalam Islam juga bisa dilihat juga dari keharusan bersikap transparan. Transparansi dalam pelaksanaan fungsi kebijakan oleh penguasa kepada rakyat yang dipimpinnya mutlak untuk dilakukan. Fungsi kontrol terhadap para pemangku kebijakan dan pemangku kekuasaan sangat mutlak untuk dilakukan. Adanya kontrol yang berkala dan terus menerus dilakukan dapat mengurangi adanya risiko penyelewengan-penyelewengan dalam kekuasaan.

Dalam persfektif maqashid al-syari'ah politik uang membawa kemudaratan ketimbang sebuah kemaslahatan. Kemudaratannya tentu dilandaskan pada akibat, dampak, ataupun pengaruh politik uang ini bagi kehidupan pribadi, keluarga, masyarakat maupun bangsa dan negara secara umum.

Larangan untuk memakan harta orang lain dengan cara batil sebagaimana telah digariskan dalam syariat baik bagi penyelenggara negara di bidang eksekutuf, legislative yudikatif, maupun kepada masyarakat umum tentu karena syariat memandang ada sisi negatif yang ditimbulkan dari perilaku politik uang ini. Secara garis besar politik uang yang selama ini telah terjadi secara meluas tidak hanya merugikan keuangan negara tetapi jua merupakan pelanggaran terhadap hak-hak sosial dan ekonomi masyarakat. Politik uang juga telah memperbesar masalah-masalah yang menyangkut kurangnya hasrat untuk terjun di bidang usaha dan mengenai kurang tumbuhnya pasaran nasional. Demikian juga politik uang mempertajam permasalahan masyarakat plural; sedang bersamaan dengan itu kesatuan 
negara menjadi lemah juga karena turunnya martabat pemerintah. Tendensitendensi itu membahayakan stabilitas politik (hlm. 225).

Politik uang juga mengakibatkan turunnya disiplin social. Uang suap itu tidak hanya memperlancar prosedur administrasi, tetapi biasanya juga berakibat adanya kesengajaan untuk memperlambat proses administrasi agar dapat menerima uang suap. Di samping itu pelaksanaan rencana pembangunan yang sudah diputuskan, dipersulit atau diperlambat karena alasan-alasan yang sama (hlm. 225).

Dalam syraiat, politik uang dinilai sebagai perbuatan mempertukarkanAllah dengan seuatu yang bersifat materi. Hal ini karena tindakan suap merupakan manifestasi ketundukan seseorang pada wujud material selain Allah yang diangkat seolah-olah senilai dengan Allah dan karenanya bertentangan dengan ajaran tauhid, sekaligus juga bertentangan dengan syariat (hlm. 225).

Pada dasarnya persoalan korupsi yang terjadi di Indonesia tidak terlepas dari politik uang. Politik uang sudah mendarah daging bagi sebagian manusia Indonesia sehingga uang menjadi alat untuk berkuasa, mengubah putusan, bahkan untuk memenangkan persaingan. Lihatlah betapa mudahnya masyarakat di Indonesia menyelesaikan persoalan hukumnya dengan menyuap aparat penegak hukum. Betapa mudahnya mengeluarkan uang untuk bias diterima menjadi pegawai di instansi pemerintah. Bahkan untuk menjadi wakil-wakil rakyat pun uangmenjadi modal untuk merebutnya. Begitu pun untuk menjadi penguasa baik bupati, gubernur, hingga presiden harus mengeluarkan uang yang sangat besar. Korupsi Pemilu sendiri dalam waktuwaktu tertentu sering ditukarnamakan dengan politik uang walaupun sebenarnya istilah politik uang memiliki dimensiu yang lebih luas karena praktik ini bias terjadi di luar momen Pemilu. Dalam terminology hokum praktik politik uang disebut sebagai tindak pidana suap.

Di akhir pembahasan buku ini penulis menegaskan bahwa dalam persfektif maqashid al-syari'ah politik uang membawa kemudaratan ketimbang kemaslahatan. Kemudaratan yang ditimbulkan oleh politik uang antara lain:

Pertama, bahwa keadilan tidak mungkin tercapai sengan adanya politik uang. Keputusan yang didasarkan pada politik uang pastilah merupakan keputusan yang bersifat diskriminatif.

Kedua, bahwa hilangnya harta benda bagi orang yang memberikan uang tentu adalah sebuah keniscayaan. Padahal menurut Islam uang dan harta itu harus digunakan untuk jalan yang diridoi oleh Allah SWT. Bagi penerimanya berarti telah mendapatkan harta dengan cara yang batil yang tentunya akan mendapatkan laknat dari Allah SWT.

Ketiga, bahwa politik uang atau suap mengakibatkan hilangnya sifat kejujuran. Kejujuran yang seharusnya menjadi modal utamabagi seorang pimpinan atau pemimpin di dalam memimpin lembaga akan hilang tergerus 
dengan kekuatan uang yang pemberinya adalah kekuatan yang sangat dahsyat untuk memenangkan persaingan.

Keempat, bahwa politik uang menimbulkan sikap pesimistis. Sikap ini sangat tidak dianjurtkan dalam agama. Manusia harus selalu berusaha dan tidak boleh berputus asa dalam rahmat Allah SWT.

Kelima, bahwa politik uang atau suap akan menumbuhsuburkan korupsi. Saat penerimaan tenaga kerja PNS yang diperjualbelikan melalui pemberian dan penerimaan suap, maka akan terjadi tindakan korupsi selanjutnya yakni penyalahgunaan wewenang atau jabatan pada saat pegawai tersebut diterima sebagai PNS.

Keenam, bahwa politik uang dalam proyek-proyek pemenangan ini menutup pintu persaingan. Padahal dengan persaingan akan didapatkan harga yang lebih murah dengan kualitas yang lebih baik,

Ketujuh, bahwa politik uang menyebabkan terbentuknya jiwa-jiwa kerdil, juga membentuk jiwa-jiwa pemalas yang mengandalkan kekuatan uang untuk mencapainya,

Keselapan, politik uang mengakibatkan seorang yang lemah kehilangan haknya atau kesempatannya,

Kesembilan, politik uangtelah mengakibatkan berkurangnya kualitas sumber daya manusia yang betul-betul terampil dan professional untuk bias terjun ke dalam dunia kerja. 